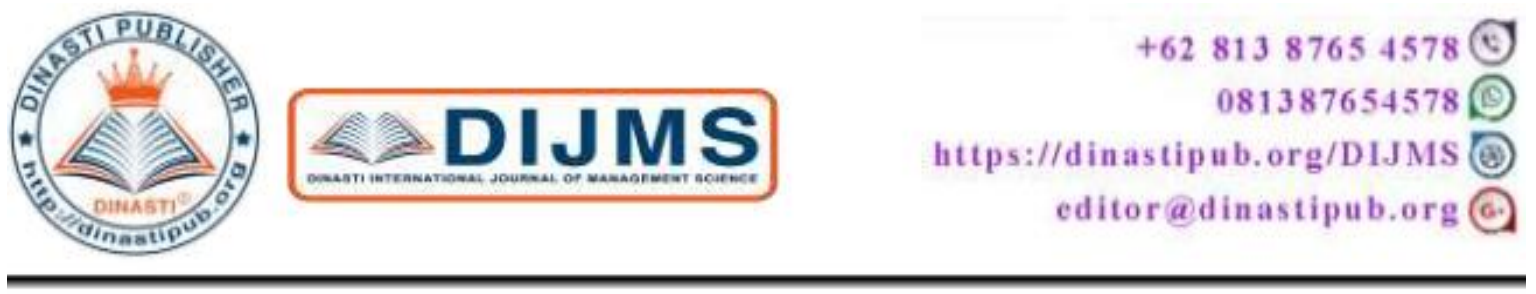

\title{
ANALYSIS OF FACTORS THAT OPPOSE BUSINESS DEVELOPMENT IN SMALL-SCALE FOOD AGRO-INDUSTRY
}

Endang Solichin ${ }^{1)}$

${ }^{1)}$ Economic Education Department, STKIP YPM Bangko

\begin{tabular}{|l|l|}
\hline ARTICLE INFORMATION & $\begin{array}{l}\text { Abstract This study aims to analyze the influence of } \\
\text { Received: 12 January 2020 } \\
\text { entrepreneurial characteristics of small-scale agro- } \\
\text { industry food business owners and the business climate } \\
\text { Issued : 15 January 2020 January 2020 } \\
\text { created through government policy on business progress, } \\
\text { testing and analyzing the dominant factors affecting the } \\
\text { progress of food agro-industry on the scale of small } \\
\text { businesses in Kediri, East Java Indonesia.The } \\
\text { questionnaire was designed in the form of a Likert scale } \\
\text { with five choices, and distributed to 140 food agro- } \\
\text { Endang Solichin }\end{array}$ \\
$\begin{array}{l}\text { E-mail: } \\
\text { Solend27@yahoo.co.id }\end{array}$ & $\begin{array}{l}\text { Kediri. The technical analysis uses Structural Equation } \\
\text { Modeling (SEM) with AMOS 4 software. The results } \\
\text { showed that the contribution of the business climate had } \\
\text { a greater influence on business progress when compared } \\
\text { with entrepreneurial characteristics. Based on these } \\
\text { findings, to spur business growth and progress in small- } \\
\text { scale agro-industry, it is necessary to have government } \\
\text { intervention in creating a conducive business climate } \\
\text { through advisory and assistance policies in accordance } \\
\text { with the needs of small-scale agro-industry businesses, } \\
\text { encouraging market } \\
\text { entrepreneurship training to improve the ability to } \\
\text { manage effort. } \\
\text { Keywords: Entrepreneurship, Business Climate, Agro- } \\
\text { food industry. }\end{array}$ \\
\hline
\end{tabular}

\section{INTRODUCTION}

In Indonesia the agricultural sector is a sector that plays an important role in the national economy, this is evidenced that in times of crisis the agricultural sector is a savior of the national economy. The reasons that underlie the importance of agriculture in the national economy, among others, are that most of the population depends their lives on the agricultural sector, the potential for large and diverse natural resources, besides that agriculture is also the basis of economic growth in rural areas because most of the population of the Indonesian 
people are in rural areas, therefore agriculture is a sector that must be developed as a foundation for the Indonesian economy.

Empowerment of farmers and the agricultural sector as a whole needs to be done to improve the economy of rural communities, therefore the development paradigm that focuses on economic growth with the most important capital strength must shift to an alternative paradigm that social development which sees development as a humanization process and focuses on social empowerment economy in a sustainable manner [1].

The industrialization strategy in the form of agribusiness development is very much needed in order to improve the agricultural sector, agro-industry as a subsitem in agribusiness needs to be encouraged because agro-industry has the potential to encourage high growth due to market share and relatively large added value, agro-industry has a large linkage both upstream and downstream, agro-industry products, especially processing agro-industries generally have a relatively high value of elasticity of demand for income when compared to agricultural products in the form of fresh or raw materials, agro-industrial activities have a base on natural resources with the support of Indonesia's large natural resources so that it is likely will have a comparative advantage and competitive advantage, agroindustry has a rural base so that it will reduce the tendency of excessive labor migration to the city.

The development of agribusiness in small-scale agro-industries which are small business units or known as smallholder agricultural businesses make a large contribution both in providing added value and in absorbing labor [2]. Small-scale agro-industry that is managed by small communities in rural areas has a role in development and has prospects to be developed, therefore it is necessary to get a better development touch so that it has the power to realize its goals, because to encourage the growth of small-scale agroindustry is very necessary business climate which is conducive. Besides that, the characteristics of entrepreneurship possessed by small scale agro-industry business owners are a factor that greatly determines business success.

\section{LITERATURE REVIEW}

The first person to show the important role of entrepreneurship in economic theory was Cantilon. The farmer was an entrepreneur who promised to pay his land for farming with a sum of money without a guarantee of the profits he would receive [3]. An entrepreneur is motivated to carry out his business activities with the potential benefits he gets, an entrepreneur buys products at a fixed price and sells them at an uncertain price so there is a risk of loss due to uncertainty in the sales price, uncertainty is an element inherent in the market.

There are five kinds of innovations or ways to do activities as an entrepreneur, namely introducing new goods or new quality, introducing new production methods, opening new markets, using new resources from raw material or semi-finished goods and making new formulations in the industry. The ability to identify new market opportunities is the main entrepreneurial activity that creates a diequlibrium in the economy [4].

Entrepreneurship refers to the nature, character and characteristics inherent in someone who has a strong will to realize innovative ideas into the real business world and can develop them, so that entrepreneurship means integrating personal, financial and resource characteristics, and therefore must have the ability to find and evaluating opportunities, gathering resources needed to benefit from those opportunities.

Small-scale business is a small-scale people's economic activity that meets the criteria for net worth or annual sales or ownership results, the net worth criteria is at most two hundred million rupiahs excluding land and buildings for businesses or having a maximum of one 
billion rupiahs of annual sales, a small-scale business that meant including informal small businesses and traditional small businesses [5].

Small businesses must be able to compete with other economic behaviors in order to survive and develop, the situation and the overall business climate can be an opportunity and also a barrier. The business climate often does not provide benefits for small businesses, so it is necessary to have government policies that are conducive to the growth of small businesses.

The conditions of small businesses are very diverse and have implications for the diversity of problems and the needs of small businesses that are not the same, this shows that government policies for small businesses need to be tailored to the specific needs of each small business. In general, small businesses are run based on short-term strategies and tend to ignore long-term businesses, this means that business profits are expected to be achieved in a short time.

Business performance can be measured by the amount of return on investment (ROI). This ROI is the profit achieved by the company, although profit can be considered as a major aspect in measuring company performance but it is not sufficient to explain the company's effectiveness in general. The measurement of business performance can be done with a balanced scorecard, a company performance appraisal method that develops four measurement perspectives, namely financial, customer, internal business processes and learning and growth.

\section{RESEARCH METHODS}

This research was conducted in Kediri, East Java, Indonesia, towards food agro-industry small business owners. Sampling was carried out by cluster random sampling method, as a sample selected small businesses that have the following characteristics, managed by the owner himself, is a business that produces materials tofu, tempeh and crackers, have observable locations and production facilities and have an annual turnover of no more than one billion. The respondents were 140 small-scale agro-industry entrepreneurs, the questionnaire was designed in the form of a Likert scale with five choices, then analyzed with structural Equation Modeling (SEM) using the AMOS 4 tool

\section{FINDINGS AND DISCUSSION}

The results of data analysis showed that there was no significant effect of entrepreneurial characteristics on progress with a path coefficient of 0.28 while the business climate had a significant effect on business progress with a path coefficient of 0.75 at the application level of 0.05

The results of the analysis indicate that the nature of responsiveness to opportunities, the nature of flexibility, the nature of hard work, the nature of self-confidence, the attitude of taking calculated risks, self-control, innovative nature, loading factors above, 0.5 this means that these traits have a role important in the formation of entrepreneurial characteristics, because an entrepreneur must focus on how to seize opportunities, an entrepreneur must be able to be flexible in various situations with anyone, must work hard, have a sense of confidence, dare to take calculated risks, be able to control yourself, and have innovative power. From these indicators of entrepreneurship, indicators of the nature of self-confidence showed the highest contribution in the formation of entrepreneurial characteristics, with a loading factor of 0.751 . So the main shaper in the characteristics of entrepreneurship is the nature of self-confidence that is a sense of optimism that his business will succeed. 
The analysis shows that the business climate has a positive and meaningful influence on business progress, it is very logical because a conducive business climate will provide opportunities for small-scale agro-industry businesses. From the indicators forming the business climate, the loading factor of competition is 0.597 . The loading factor of funding, targets, information and partnerships above 0.6 and the highest loading factor forming the progress of the business is the partnership that is 0.811 , this means that the problem of partnership for small scale agro-food industry entrepreneurs gives an important role in creating a conducive business climate for business progress .

Lamda values for the four variables that explain business progress, each above 0.40 , it can be concluded that the four variables together present the unidimensionality for the latent variable of business progress. Marketing factor loading factor is 0.548 while for net profit, the number of production and the number of customers is above 0.70 and the highest is the number of customers by 0.871 . This means the number of customers provides the largest contribution to the formation of business progress.

Empirical findings indicate that the contribution of entrepreneurial characteristics of agro-industry entrepreneurs in small-scale businesses is weak when compared to the contribution of the business climate, business progress is not much supported by the entrepreneurial characteristics of small-scale agroindustry entrepreneurs. According to observations, business progress was driven more by an increase in income, an increase in population and high population mobility with tourism objects supported by inter-regional tourism bureaus causing an increase in demand for products.

Business progress that is not supported by the ability of entrepreneurial characteristics gives a negative signal in the long run, because it shows that business progress is not sustainable, because of the dependence on external factors, namely the business climate, not the entrepreneurial character that is owned or attached to an entrepreneur. That's why business progress like that is very temporal means that business progress is not sustainable.

Ideally, the ability of entrepreneurial characteristics is strong, the business climate is conducive, therefore there is a need for government policy intervention to improve entrepreneurial capacity such as the need for training, training can improve the ability to manage small-scale agro-industry businesses so that ultimately it can increase income [6]. Besides that there is also a need for assistance in accordance with the needs of small businesses, the government's support for small businesses is reflected in the law of the Republic of Indonesia Number 9 of 1995, concerning small businesses, which mandates that the government must be aligned with small businesses, in the form of funding, infrastructure, information, partnerships, protection and competition licensing. Without any alignments, it is difficult for small businesses to grow and develop due to their inability to compete with big businessmen in terms of capital, infrastructure and information. The government realizes that small businesses such as agro-industry, small-scale food in the Indonesian economic crisis in 1998 were the last bastions of Indonesia's economic defense system, when many conglomerates were falling. But on the other hand the alignment to the development of small businesses is an unpopular policy when compared to encouraging big businesses in terms of a growth leap, where the leap or high growth is a political commodity for rulers and politicians, so the policy of alignments to businesses small businesses appear only as patchwork or sweeteners for power agents, because the support for these small businesses growth will not be as fast as compared to encouraging big businesses, although in the long run it will become pillars of economic strengthening Indonesia. 
This is why the success of a dominant business is determined by the business climate is very vulnerable and not sustainable, it will be very different if the success of the business is dominated by the ability of entrepreneurial characteristics possessed by small-scale agro-food entrepreneurs, meaning that business progress does not depend on the mercy of the government in favoring to small businesses by creating a conducive business climate. The protective attitude of the government in protecting these small businesses is likely the small businesses become spoiled and very vulnerable so that they become an obstacle to quickly grow into a medium-sized business group.

The ability to compete with small-scale agroindustry entrepreneurs must be improved by changing their mindset, from competing to win to competing to excel, meaning that they must jump from the red zone to the blue zone built with creativity and innovation [7]. The ability to compete lies in creativity and innovation in creating added value, especially in small-scale agro-industry food businesses are likely to increase greater added value. Small businesses do not seem to care so much about the public interest such as health elements for consumers, this actually becomes an opportunity that can be taken by agroindustry entrepreneurs on a small scale, such as how to reduce or replace elements that can interfere with health, use of preservatives, dyes and so on, which are expected to increase public awareness of health in line with increasing community income.

\section{CONCLUSION AND SUGGESTION}

The business climate has a greater influence on business progress, when compared to the entrepreneurial characteristics possessed by small-scale agro-food industry owners. The progress of the resulting business due to conducive business climate and weak entrepreneurial characteristics is an unsustainable business progress.

Government intervention is needed to create a conducive business climate, to stimulate business growth and progress in small-scale food agro-industry, through various assistance and assistance policies as needed, such as encouraging market creation, providing entrepreneurship training to improve the ability to manage their businesses.

The results of this study support the opinion of Aldrich and Zimmer who suggest that entrepreneurship is more a contingency phenomenon, therefore business progress is more determined by situational factors so that entrepreneurial characteristics alone which are factor traits are not enough to support business progress without conducive situation factors in this case business climate [8].

\section{REFERENCE}

[1] Munandar, Aris. (2002). Pembangunan Nasional, Keadilan Sosial dan Pemberdayaan Masyarakat, Jurnal Universitas Paramadina vol 2 No. 1 September $2002: 12-24$

[2] Saragih, Bungaran. (2002). Pengembangan agribisnis dalam pembangunan ekonomi nasional menghadapi abad ke-21 Jurnal Volume 7.2

[3] Philipsen, Kristian. (1998). Entrepreneurship as Organizing, A literature study of entrepreneurship, June 9-11, Southern Denmark Business School, Bornholm, Denmark

[4] Schumpeter, JA. (1934). The Theory of Economic Development, Cambridge, MA : Harvard University Press.

[5] Undang-Undang Republik Indonesia Nomor : 9 tahun 1995 tentang Usaha Kecil 
[6] Sri Harini, ( 2016). Pengaruh Pelatihan Entrepreneurship dan manajemen usaha terhadap pendapatan Usaha Mikro makanan dan minuman, Jurnal Entrepreneur dan Entrepreneurship, Vol 3 Page 73-80

[7] Howkins, J. 2001. The Creative Economy : How people make money from Ideas. London-England : Penguin Books Ltd. 80 Strand

[8] Aldrich, Howard and Zimmer, Catherine. (1986). Entrepreneurship through Social Network Pp 3-23 In : D Sexton and R Smiler (Eds) The Art and Science of Entrepreneurship, New York. 